UDC 631.43

\title{
EVALUATING AGROGENIC STRUCTURIZATION OF SOIL VARIANTS UNDER DIFFERENT APPLICATION MODES IN THE FOREST-STEPPE
}

\author{
S. Yu. Bulygin ${ }^{1}$, O. V. Demydenko ${ }^{2, *}$, V. A. Velychko ${ }^{3}$, M. A. Tkachenko ${ }^{4}$, S. V. Vitvitskyi ${ }^{1}$ \\ ${ }^{1}$ National University of Life and Environmental Sciences of Ukraine, \\ 15, Heroyiv Oborony Str., Kyiv, Ukraine, 03041 \\ ${ }^{2}$ Cherkasy State Agricultural Experimental Station, NSC «Institute of Agriculture NAAS», \\ 13, Dokuchayeva Str., Kholodnianske village, Smila District, Cherkasy Region, Ukraine, 20731 \\ ${ }^{3}$ NSC «Institute for Soil Science and Agricultural Chemistry named after O.N. Sokolovsky» \\ 4, Tchaikovsky, Str., Kharkiv, Ukraine, 61023 \\ ${ }^{4}$ NSC «Institute of Agriculture NAAS», \\ 2-B, Mashynobudivnykiv Str., Chabany, Kyiv-Sviatoshyn District, Kyiv Region, Ukraine, 08162 \\ E-mail:agrogumys@ukr.net 2,*,agrovisnyk@ukr.net ${ }^{3}$
}

Received October 05, 2020 / Received November 05, 2020 / Accepted November 20, 2020

\begin{abstract}
Aim. To develop the general normalized statistical model of organizing the structural state of the investigated soils, to determine the vector of direction and criteria of appraising structurization of soil variants in the Forest-Steppe on macroand microaggregate levels of organization to obtain objective and integral information about the quality status of soil structure and to determine the critical level of degradation, when the residual resistance against the latter is lost. Methods. Field (investigated agrophysical properties of the most common variants in the Forest-Steppe of Ukraine: gray forest soil, meadow-chernozem soil, typical chernozem), laboratory (air-dried sieving of soil), statistical-analytical (fractal, factor, cluster, non-parametric statistics). Results. The combined study of the change in the state of soil structure in the most common soils in the Forest-Steppe on two hierarchy levels demonstrated the presence of soil-genetic interval in valuable structural units. The appraisal of several distribution series of structural soil units by dimensions in terms of stability using fractal indices and the structurization of agronomically non-valuable fraction of microaggregates of $<0.25 \mathrm{~mm}$ enhanced the reliability of the approximation for the exponent trends in equations of unit distribution to the level of $\mathrm{R}^{2}>0.7$ and demonstrated the persistence and anti-persistence of the distribution series, namely, stability or trend. The re-grouping of soil structure constituents occurs by dimensions depending on the soil type, and microaggregates in the amount of 0.25 $\mathrm{mm}$ are mostly involved in structural aggregates of $1-0.25 \mathrm{~mm}$ and less so in more valuable structural units of $>1 \mathrm{~mm}$. Conclusions. It was determined that meadow-chernozem soil was the most resistant to anthropogenic impact (introduction of mineral fertilizers and treatment methods). Its coefficient of macroaggregation was at a high level and in case of sowing perennial grasses with the introduction of fertilizers - at a very high level. Gray forest soil was found to be less resistant to the introduction of mineral fertilizers and typical chernozem was the most susceptible to agrophysical degradation: the macroaggregation coefficient was at a very low level. The microaggregation coefficient increased from typical chernozem to gray forest soil and meadow-chernozem which demonstrated the increase in humus content and biogenicity in the presented series of soil variants.
\end{abstract}

Key words: structural state of soil, microaggregates, macroaggregates, elementary soil particles, factor analysis, cluster analysis, factor analysis, microaggregation coefficient, macroaggregation coefficient, genetic-soil interval of valuable aggregates.

DOI: https://doi.org/10.15407/agrisp7.03.040

\section{INTRODUCTION}

The parameters of physical structure of soil are among the main fast-changing properties of soil vari-

(C) S. Yu. BULYGIN, O. V. DEMYDENKO, V. A. VELYCHKO, M. A. TKACHENKO, VITVITSKYI S. V., 2020 ants in the Forest-Steppe. During the first years after plowinge, there is a sharp change in their structural state, density of their structure, and aqueous-physical properties (Medvedev V, 2016). The studies, conducted in the Forest-Steppe of Ukraine demonstrated the norms for the changes in physical parameters of arable 
soils and terminal values for the parameters of their indices, provided for the forecast on productivity loss of agricultural crops under deterioration of the structural state and compaction (Medvedev V et al, 2012; Bulyhin S et al, 2014; Medvedev V et al; 2014). The studies also determined the impact of multiple passages of heavy machinery in the fields on the decrease in the yield of agricultural crops which may range from 10 to $50 \%$ (Bryk M, 2004). The variation in the physical properties of the arable layer of soil variants in the Forest-Steppe zone is related both to genetic specificities and, considerably, to the duration and character of their use and the level of agriculture efficiency in general (Cheverdin Yu, 2008). The optimal equilibrium structure density for the main types of soil variants in the Forest-Steppe is $1.11-1.25 \mathrm{~g} / \mathrm{cc}$ with the content of agronomically valuable aggregates of $>70 \%$. From the standpoint of optimizing physical properties (structural state) of soil, it is necessary to introduce the measures in creating positive humus balance and to maintain it at the non-deficiency level after achieving the optimum (Horn R and Fleige H, 2000). The degradation of physical state of soil is viewed as consistent deterioration of physical properties of soil, its structural state, first and foremost, and structure density, which leads to deterioration in the aqueous, air, nutrition regimes and, finally, to a considerable decrease in soil fertility (SlowinskaJurkewicz A et al, 2004).

During the deterioration of the structural state, the equilibrium density of the structure in agrogenic soil variants increases as compared to natural soils-analogues, a new phenomenon arises - consolidation of structural aggregates and a decrease in intra-aggregate porosity which aggravates the conditions of aqueous-mineral nutrition of plants (Gorban V, 2016). Non-structured and compacted soils may have horizontal prolonged macropores even under moderate burden which are notable for platy or subplaty soil structure, which brings additional changes to agrophysical properties of the arable layer. In the opinion of V.V Medvedev (Medvedev V, 1990), the decrease in the depth and number of tillage or the refusal from soil tillage, high agriculture efficiency and introduction of organic fertilizers or leaving plant remains in the field gradually improves the structural composition of soil under intense tillage, and in case of zero tillage the process of chernozem structure restoration starts.

The origin, formation, stability of structural units and, on the contrary, the processes of losing aggregate structure, its degradation are the processes of direct impact on complicated fundamental physical-chemical and biological processes in soil. Soil structure affects carbon cycle (Jimenez J, 2011), fertility, environment and humus regimes (Bazykina G, 2014; Kershens M, 1992; Kuznetsova I et al, 2011; Kuznetsova I et al, 2014; Medvedev V, 2013; An S et al, 2008; Elliott E, 1986; Garcia-Oliva F et al.,2004) as it is a result of the combined action of different physical-chemical, biological and physical processes of soil formation as well as one of the main quality and quantity traits of agrocenosis stability (Six J et al, 2004). Fundamental properties of soil variants and the main processes, defining their inner life and functions in biosphere, depend on the shares of large and small structural units (Pirmoradian $\mathrm{N}$ et al, 2005; Nichols $\mathrm{K}$ and Toro $\mathrm{M}, 2011$ ). Soil variants with prevailing macroaggregates usually contain more organic substances and nutrients, they are less susceptible to erosion and have optimal physical regimes (Kholodov V, 2013).

The changes in agrophysical properties of soils in the Forest-Steppe of Ukraine are manifested in different forms and to a different degree under current conditions of agrogenic burden, which was called "agrophysical degradation". Accurate estimation of the character of changes, leading to the decrease in soil fertility, require the knowledge of both decreasing parameters and the forms of its manifestation. Multiple effect of travel pressure of heavy agricultural machinery during soil tillage and harvesting causes the deterioration of the structural-aggregate condition of arable and subarable layer which results in the compaction of the humus horizon in general. Higher agrogenic loading of soils resulted in the change in their morphological, aqueous-physical properties, and other factors of fertility decrease (Medvedev V, 2013).

Physical degradation of soil variants is manifested in the deterioration of soil structure and, as a result, the whole complex of physical properties, i.e. in ruination of the physical basis of soil fertility, where excessive burden of mechanical, chemical, aqueous or biological nature is applied. Physical degradation of soil may be conditioned by different natural factors and get developed in agrocenoses due to changes in climatic conditions, natural processes of wind and water erosion, desertification, etc. Physical degradation of soils may also be caused by different catastrophic processes of natural and anthropogenic character, so the investigation of the impact of the abovestated factors of the structural status in the Forest-Steppe is urgent in current soil-ecological conditions (Medvedev V et al, 2012; Bulyhin S et al, 2014). 
The simplest method of quantitative estimation of soil structure is sieving air-dried soil through a set of sieves of different sizes. The sieves of $0.25,0.5,1.0$, 2.0, 3.0, 5.0, 7.0, $10.0 \mathrm{~mm}$ are usually used to obtain the distribution of structural units by the following sizes: from particles of $<0.25 \mathrm{~mm}$ to lumps of $>10 \mathrm{~mm}$ (Medvedev V, 2013; Six J et al, 2004). Sieving yields eight indices to characterize soil structure in air-dried state. However, the conventional procedures of processing the analysis results are aimed at bringing all the obtained data down to the limited number of indices. The interpretation of results is complicated by the fact that in different soil-climatic conditions the content of agronomically valuable aggregates is also used in quantitative characterization of the structure, and different references present different dimensional parameters of these fractions: most researchers refer fractions of $7-0.5 \mathrm{~mm}$ or $10-0.25 \mathrm{~mm}$ to agronomically valuable aggregates (Pirmoradian N et al, 2005; Nichols K and Toro M, 2011; Kholodov V, 2013). According to the abovementioned methodological approach, only one value of the structuredness coefficient is obtained from rather a large amount of data (distribution by size) which complicates detailed characterization of soil structure.

The aim of the study was to develop the general normalized statistical model of organizing the structural state of the investigated soils, to determine the vector of direction and criteria of appraising structurization of soil variants in the Forest-Steppe on macro- and microaggregate levels of organization to obtain objective and integral information about the quality status of soil structure and to determine the critical level of degradation, when the residual resistance against the latter is lost.

\section{MATERIALS AND METHODS OF STUDIES}

The study was conducted in 2016-2018. Three objects of study, located within the Forest-Steppe soilecologic subzone with enhanced moisturization (Polupan M, 2019) and hydrothermal coefficient (HTC) of 1.1-1.2, were selected.

A long-term experiment of the Chair of Agrochemistry and Quality of Products of Plant Cultivation named after O.I. Dushechkin, the National University of Life and Environmental Sciences of Ukraine was started in 1956 ( $50^{\circ} 47^{\prime}$ north latitude, $30^{\circ} 23^{\prime}$ east longitude, 180 $\mathrm{m}$ above sea level) (Zaryshnyak A et al, 2016) in the Right-Bank Forest-Steppe. The soil of the experimental plot was meadow-chernozem low-humus carbonate medium-clay heavy-loamy soil on forest-like clay. The arable layer contained $4.09 \%$ humus, $27.0 \mathrm{mg} / \mathrm{kg}-$ mobile phosphorus, $89.3 \mathrm{mg} / \mathrm{kg}$ - exchange potassium.

The multifactor experiment of the department of agronomic soil science, NSC Institute of Agriculture, NAAS $\left(50^{\circ} 26^{\prime} 13^{\prime \prime}\right.$ north latitude, $30^{\circ} 30^{\prime} 20^{\prime \prime}$ east longitude, $120 \mathrm{~m}$ above sea level) was started in 1992. The experimental work was done in a long-term multifactor experiment in the Right-Bank Forest-Steppe, on gray forest low-humus heavy-loamy light-clay carbonate on forest-like clay. Initial soil parameters $(0-20 \mathrm{~cm})$ : total humus $-1.44 \%, \mathrm{pH}_{\mathrm{KCl}}-4.6$, hydrolytic acidity $3.6 \mathrm{mg}$-eq/100 g of soil, exchange calcium and magnesium -3.9 and $0.58 \mathrm{mg}-\mathrm{eq} / 100 \mathrm{~g}$ of soil. The system of mineral fertilization in the experiment included three doses (from the ordinary to double dose) - 160 , 240 , and $320 \mathrm{~kg} / \mathrm{ha}$ NPK, organic fertilization -10 t/ha of manure in the first rotation, by-products (straw of cereals), clover cover crop - in the second and third rotations. Lime was added in 1992 and 2006 in the 1.0 and 1.5 doses by hydrolytic acidity $\left(1.0 \mathrm{Ha}=5 \mathrm{t} / \mathrm{ha} \mathrm{CaCO}_{3}\right)$.

Multifactor field experiment of Panfilska Experimental Station of NSC Institute of Agriculture, NAAS of Ukraine $\left(50^{\circ} 13^{\prime} 22^{\prime \prime}\right.$ north latitude, $34^{\circ} 44^{\prime} 46^{\prime \prime}$ east longitude, $128 \mathrm{~m}$ above the sea level) was started in 2000 in the Right-Bank Forest-Steppe, located in Yahotyn District, Kyiv Region. The study was conducted on typical low-humus heavy-loamy light-clay chernozem on forest-like clay. According to the data of agrochemical analysis of the initial samples, the content of humus in the arable layer varied from 3.08 to $3.15 \%$, in the subarable layer - from 2.72 to $2.9 \%$. Soil was characterized by a high content of phosphorus - 233-270 mg/ $\mathrm{kg}$ of soil in the arable layer $(0-20 \mathrm{~cm})$ and $227-270$ $\mathrm{mg}$ - in subarable layer $(20-40 \mathrm{~cm})$, high and moderate content of exchange potassium (80-100 mg/kg of soil). The reaction of soil solution was weak-acid $\left(\mathrm{pH}_{\mathrm{KCl}}=\right.$ 5.96), the saturation rate of the absorbing complex with alkali was high (85-99\%).

The schemes of long-term experiments are presented in Table 1.

The structural-aggregate composition of soils was determined by sieving (by the method of N.I. Savvinov) 86 samples of the investigated soil, each of which was an average sample among 4 selected samples of soil horizons, i.e. 344 samples of soils from the Forest-Steppe of Ukraine were actually analyzed. The study of the level of elementary soil particles was conducted by the method of S.Yu. Bulyhin and F.M. Lisetskyi (Bulyhin S. and Lisetskyi F., 1991), which is 
based on determining the content of non-aggregated elementary soil particles (ESP) and aggregates in soil by sieving on the sieves with the fraction of $<0.25$ $\mathrm{mm}$ into the constituent subfractions: $0.2 \mathrm{~mm}, 0.16$ $\mathrm{mm}, 0.125 \mathrm{~mm}, 0.1 \mathrm{~mm}, 0.071 \mathrm{~mm}, 0.05 \mathrm{~mm}$ and $<0.05 \mathrm{~mm}$. The simultaneous study of the change in the condition of soil variants on several levels of their organization ensures obtaining objective and comprehensive information and determining the level, when the negative process of agrophysical degradation is manifested. Thus, in addition to the aggregate level of soil system, the level of microaggregates and ESP was studied for more objective appraisal of the changes in soil status under the impact of agrogenic loading. The granulometric composition was defined according to N. A. Kachynsky. The fractal estimation of the distribution series for structural units was done according to K.G. Moiseev (Moiseev K et al, 2014).

The generalization of the study results and the interpretation of the data of structural state of soil was done using STATISTICA-10 program with non-parametric statistics, factor, cluster, fractal and correlation analysis (Kholodov V et al, 2016).

\section{RESULTS OF STUDIES}

The results of air-dried sieving and distribution of structural units, microaggregates and ESP by dimensions in the soil layer of $0-40 \mathrm{~cm}$ in the investigated soil are presented in Fig. 1. The distribution of units is shown on normal $(a)$ and logarithmic scales $(b)$ which demonstrates the specificities of distribution for microaggregates and ESP depending on agrogenic loading and post-agrogenic maintenance.

The trends and calculated exponential equations of distribution demonstrate that the curves of distribution of units by dimensions are reliable $\left(\mathrm{r}^{2}=0.72-0.85 \pm\right.$ \pm 0.02 ), and Hurst exponent and fractal dimensions demonstrate that out of all the investigated objects only typical low-humus heavy-loamy light-clay chernozem on forest-like clay was characterized by stable persistent trendy distribution series for structural units. Gray forest low-humus heavy-loamy light-clay soil on carbonate forest-like clay and meadow-chernozem low-humus carbonate medium-clay heavyloamy soil on forest-like clay are anti-persistent $(\mathrm{H}<$ $0.5)$, unstable, i.e. under the impact of agrogenic loading these soil objects lose their ability to counteract its effect easily.

Regardless of the fact that on fallow analogues the average content of the most valuable fraction of structural units was the highest (34\%), trend stability of the distribution of structural units is anti-persistent as compared to the distribution of structural units of meadowchernozem low-humus carbonate heavy-loamy soil on forest-like clay but lower than the distribution of structural units of gray forest low-humus heavy-loamy light-clay soil on carbonate forest-like clay.

It was determined that the reliability of the trend in exponential equations for the distribution of structural units was defined by structurizing the distribution of the fraction of soil aggregates $>0.20 \mathrm{~mm}$ and soil microaggregates of $0.2-1.0 \mathrm{~mm}$, non-aggregated mineral particles $(<0.1 \mathrm{~mm})$. The interpretation of structured distribution of particles of $<0.25 \mathrm{~mm}$ on logarithmic scale demonstrated that the highest number of microaggregates of $0.2-0.1 \mathrm{~mm}$ was formed on the fallow variant, while the lowest one was seen on meadowchernozem soil and gray forest soil.

The factor analysis is based on the hypothesis, defining current internal parameters and properties, the

Table 1. The schemes of multifactor field experiments

\begin{tabular}{|c|c|c|c|c|c|}
\hline \multicolumn{2}{|c|}{$\begin{array}{l}\text { Meadow-chernozem low-humus } \\
\text { carbonate medium-clay heavy-loamy } \\
\text { soil on forest-like clay }\end{array}$} & \multicolumn{2}{|c|}{$\begin{array}{l}\text { Gray forest low-humus heavy-loamy light- } \\
\text { clay on carbonate forest-like clay }\end{array}$} & \multicolumn{2}{|c|}{$\begin{array}{c}\text { Gray forest low-humus } \\
\text { heavy-loamy light-clay } \\
\text { on carbonate forest-like } \\
\text { clay }\end{array}$} \\
\hline $\begin{array}{l}\text { Sugar beet following } \\
\text { spring wheat }\end{array}$ & $\begin{array}{l}\text { Control (no fertilizers) } \\
\text { NPK } 1.0 \\
\text { NPK } 1.5 \\
\text { Control } 1 \text { (no fertilizers) } \\
\text { NPK } 1.5\end{array}$ & $\begin{array}{l}\text { Spring wheat } \\
\text { following soybeans }\end{array}$ & $\begin{array}{l}\text { Control (no fertilizers) } \\
1.0 \mathrm{ng} \mathrm{CaCO} \\
\mathrm{NPK} \\
2 \mathrm{NPK}+\underset{-}{1.0 \mathrm{ng} \mathrm{CaCO}_{3}}\end{array}$ & $\begin{array}{l}\text { No-till } \\
\text { No-till } \\
\text { Plowing } \\
\text { Plowing } \\
\text { Plowing }\end{array}$ & $\begin{array}{c}1 \mathrm{NPK} \\
2 \mathrm{n} \mathrm{NPK} \\
1 \mathrm{n} \mathrm{NPK} \\
2 \mathrm{n} \text { NPK } \\
\text { no fertilizers }\end{array}$ \\
\hline & - & \multicolumn{4}{|c|}{ Fallow } \\
\hline
\end{tabular}


BULYGIN et al.
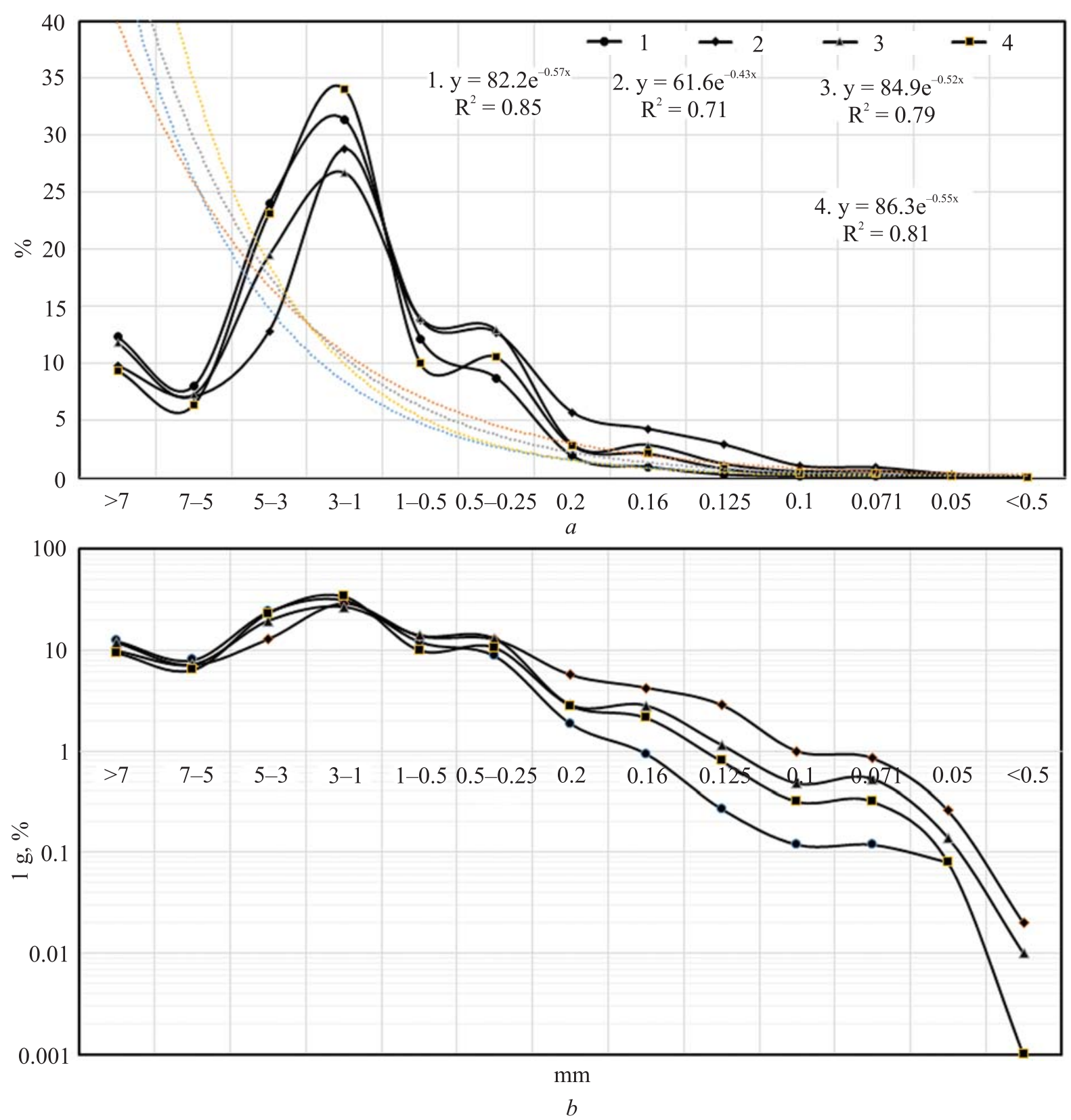

Fig. 1. The re-distribution of structural units, microaggregates and ESP in the $0-40 \mathrm{~cm}$ layer of soil variants in the RightBank and Left-Bank Forest-Steppe: $a$-distribution on normal scale; $b$-distribution on logarithmic scale. 1, 2, 3, 4 (objects according to experiments in Table 1)

number of which is insignificant, so there is a possibility to determine many traits, studied in terms of a smaller number of more fundamental characteristics, which are not subject to direct calculations: factors $\mathrm{F}_{1}-$ $\mathrm{F}_{3}$ (Demydenko O, 2019). The results of calculations demonstrate that the whole complex of structural units of soil is related to the main factor $\left(\mathrm{F}_{1}\right)$. Factor loading by the main factor $\mathrm{F}_{1}$ was the densest with the groups of structural units from $3-5 \mathrm{~mm}$ to particles of $0.1 \mathrm{~mm}$, except for particles of $0.5-0.25 \mathrm{~mm}$, and was defined by close correlation $r>0.75$ (Table 2 ).
The units of 3-5 mm, 1-3 $\mathrm{mm}$ are related to $F_{1}$ with direct functional bonds: $r=+0.85-0.90$, and the groups of units in a wide range from $1 \mathrm{~mm}$ to $0.1 \mathrm{~mm}$ - with reverse bonds on a high level of correlation: $r=-0.78-$ -0.90 , which demonstrates their self-regulating function. $48 \%$ of $\mathrm{F}_{1}$ dispersion from the total one were per $\mathrm{F}_{1}$. The units of $>5 \mathrm{~mm}$, lumps $(>7 \mathrm{~mm}$ ) had factor loading with $\mathrm{F}_{2}$ on the level of direct correlation of medium level $(\mathrm{r}<0.70)$, and non-aggregate particles from 0.071 to $<0.05 \mathrm{~mm}$ with factor $\mathrm{F}_{3}$ werre related by reverse correlation, when $\mathrm{R}<-0.70$. It should be noted that the 
amount of agronomically valuable aggregates had factor loading at $\mathrm{R}>0.70$ with factor $\mathrm{F}_{3}$, which referred to $16 \%$ dispersion of the traits under investigation. High factor loading in terms of $F_{1}(r=-0.97)$ was observed by fraction of soil particles $<0.25 \mathrm{~mm}$, which defined its self-regulating function in the combination of soil microaggregates. The results of fractal and factor analysis helped review the notions of agronomically valuable interval of structural units, used in conventional agroscientific studies: $0.25-10(7 \mathrm{~mm})$. Factor analysis by the reliability and direction of factor loading helped define a new series of structural units of soil, which can be more accurately called genetic soil interval of valuable aggregates (GSIVA). This interval for soil objects under investigation was $5-0.1 \mathrm{~mm}$.

The clusterization of structural units of soil demonstrated three separate clusters of aggregate groups. The first cluster, which united macroaggregates of 0.25 $5 \mathrm{~mm}$, non-valuable aggregates and lumps, had a total of $24 \%$ of similarity. Within this cluster, there was grouping of structural units of $1-0.25 \mathrm{~mm}$ and 1$0.5 \mathrm{~mm}$ (15\%); 1-3 $\mathrm{mm}$ and 3-5 mm (10\%); nonvaluable lumps $(10 \%)$. The latter two groups of aggregates formed a subcluster on the similarity level of $20 \%$. The second cluster of structural units united a complex of soil particles of $<0.25 \mathrm{~mm}$, structured into microaggregates and mineral particles on the level of $5 \%$ similarity. The third cluster united the groups of units of $<0.25 \mathrm{~mm}, 0.16-0.2 \mathrm{~mm}, 0.7 \mathrm{~mm}$ on the similarity level of $10 \%$ and was combined with the cluster of ESP on the level of $16 \%$ similarity, which, in its turn, created a cluster with macroaggregates at the level of $36 \%$ similarity which demonstrated different quality condition and quantitative composition of different groups of structural aggregates. The separate (fourth) cluster with $10 \%$ similarity level was made out of groups of agronomically valuable $(0.25-$ $7.0 \mathrm{~mm})$ and soil-genetically valuable aggregates $(5.0$ $0.1 \mathrm{~mm}$ ), which demonstrated their highest detachment and remoteness from other clusters of structural units, and the combination of these groups of units into one cluster demonstrated their similarity in the appraisal of the structural state of soil.

The statistical parametrization of structural units which have reliable direct correlation with factors $\mathrm{F}_{1}$ $\mathrm{F}_{3}$ is shown in Table 3. On average, 18.9 and $26.1 \%$ of the most valuable structural aggregates of 3-5 and 3$1 \mathrm{~mm}$ were registered. The amplitude interval was 28.8 and $29.1 \%$, and the normalized interval was 9.1 and $8.8 \%$. The variation coefficient exceeded $30 \%$ which demonstrated the instability of the content of the most valuable units in the soil objects under investigation.

The fractions of macroaggregates of $1-0.5 \mathrm{~mm}, 1-$ $0.25 \mathrm{~mm},<0.25 \mathrm{~mm}$ in terms of $F_{1}$ with a strong cause-consequence effect had the average values of 16 and $26.9 \%$, and by median -12.9 and $24.6 \%$. The amplitude interval was 31.6 and $38.7 \%$, the normalized one -9.3 and $13.4 \%$ by the variation coefficient, which exceeded $30 \%$.

Soil particles of $<0.25 \mathrm{~mm}$ were on average $8.77 \%$, by the median $-7.57 \%$, by the amplitude interval $21.5 \%$, and with normalized interval $-8.23 \%$ (Table 3 ). The variation coefficient was $>70 \%$, which demonstrated not very high instability of soil particles of $<0.25 \mathrm{~mm}$. The structurization of the fraction of soil particles demonstrated that in the combination of soil objects, the fraction of $0.16-0.20 \mathrm{~mm}$ had $5.19 \%$; the one of $0.125 \mathrm{~mm}-1.31 \% ; 0.1 \mathrm{~mm}-0.42 \%$, and by the median $-4.64,0.74$ and $0.24 \%$ respectively. The variation coefficient for the fraction of $0.16-0.20 \mathrm{~mm}$ was $>70 \%$, and that for smaller fractions exceeded $100 \%$, which demonstrated high sensitivity of the constituents of the $<0.25 \mathrm{~mm}$ fraction to agrogenic impact, thus, the character of their behavior was a good indicator of qualitative and quantitative changes in the

Table 2. Factor loading of the structural composition constituents in the investigated soils

\begin{tabular}{l|c|c|c}
\hline \multirow{2}{*}{$\begin{array}{l}\text { Size of fractions of } \\
\text { aggregates, } \mathrm{mm}\end{array}$} & \multicolumn{3}{|c}{ Factor loading } \\
\cline { 2 - 4 } & $\begin{array}{c}\text { Factor }- \\
1\left(\mathrm{~F}_{1}\right)\end{array}$ & $\begin{array}{c}\text { Factor }- \\
2\left(\mathrm{~F}_{2}\right)\end{array}$ & $\begin{array}{c}\text { Factor }- \\
3\left(\mathrm{~F}_{3}\right)\end{array}$ \\
\hline $3-5$ & $0.90 *$ & -0.02 & -0.15 \\
$1-3$ & $0.85 *$ & -0.20 & -0.14 \\
$1-0.5$ & $-0.78 *$ & -0.09 & 0.42 \\
$1-0.25$ & $-0.87 *$ & -0.22 & 0.27 \\
0.20 & $-0.78 *$ & -0.32 & -0.39 \\
0.16 & $-0.87 *$ & 0.12 & -0.15 \\
$0.16-0.20$ & $-0.89 *$ & -0.15 & -0.31 \\
0.125 & $-0.90 *$ & 0.15 & 0.07 \\
0.10 & $-0.80 *$ & 0.24 & 0.18 \\
$<0.05$ & 0.25 & -0.42 & $-0.74 *$ \\
$0.071-<0.05$ & 0.08 & -0.36 & $-0.72 *$ \\
$7.0-0.25$ & 0.37 & $-0.79 *$ & 0.44 \\
$5-0.10$ & -0.50 & $-0.70 *$ & -0.25 \\
$>7.0$ & 0.63 & $0.70 *$ & -0.22 \\
$<0.25$ & $-0.97 *$ & -0.01 & -0.16 \\
$>7.0+<0.25$ & -0.37 & $0.79 *$ & -0.44 \\
Total dispersion by factor & 0.48 & 0.16 & 0.12 \\
\hline
\end{tabular}

Note. *reliable value of factor loading 
structural condition of the investigated soil variants (Table 3).

The groups of soil macroaggregates, referenced to $F_{2}$ by the cause-consequence character $(\mathrm{R}>-0.70)$, were an agronomically valuable interval of $7-0.25 \mathrm{~mm}$ and genetically valuable interval of structural units, whose content was $82.0-83.8 \%$ on average. The amplitude interval $(\Delta)$ for these groups of aggregates was 25.2 $31.1 \%$, and the normalized one $-6.40-9.10 \%$ by the variation coefficient of $<10 \%$, which demonstrated the stability of the content of valuable units in the investigated soils.

The variation coefficient of structural soil units of the non-valuable group $(>7+<0.25 \mathrm{~mm})$ was over $25 \%$, which demonstrated increased variability of the mentioned fraction of structural units. The amplitude interval was $25.9 \%$ at the normalized interval of $6.56 \%$. The variation coefficient was $26.9 \%$, which demonstrated high variability of this group of structural units. The fraction of soil particles of $0.071 \mathrm{~mm}$ and $<0.05 \mathrm{~mm}$, referenced to $\mathrm{F}_{3}$ by the cause-consequence relation, was 2.05 and $1.95 \%$ with the variation coefficient of $121.3 \%$, which demonstrated their high variability under the impact of agrogenic loading in different types of soils. The estimation of paired coefficients of correlation between the groups of structural units and constituents of soil particles of the $>0.25 \mathrm{~mm}$ fraction, which are referenced by $F_{1}$ in terms of direct and reverse correlation, demonstrated a reverse correlation between the number of units of 3-5 and 1-3 $\mathrm{mm}$ and the content of $>1 \mathrm{~mm}$ fractions.

A direct correlation was found between the fractions of structural units of $>1 \mathrm{~mm}$ to $0.1 \mathrm{~mm}$ (Fig. 2) on the level of strong correlation. With the decrease in the size of soil particles from $0.16 \mathrm{~mm}$ down to $0.1 \mathrm{~mm}$, the correlation was weakened to the average level which demonstrated the enhanced inertness of soil particles.

The determined regularity was well traced in the charts (Fig. 2) of the dependence of the content of macroaggregates of 3-5 and 3-1 $\mathrm{mm}$ with structured groups of microaggregates of $<0.25 \mathrm{~mm}$. It was determined that there were $0.64-0.93$ points of the content of the units with the size of $1-0.5 \mathrm{~mm}, 1.03-1.26$ points of the units of $1-0.25 \mathrm{~mm}$ per one point of decrease or increase in the content of the mentioned group of macroaggregates.

Further analysis of the structurization of the fractions of investigated soils showed that while decreasing the

Table. 3. The statistical model of the content of structural units, microaggregates in the investigated soils

\begin{tabular}{|c|c|c|c|c|c|c|c|}
\hline \multirow{3}{*}{$\begin{array}{l}\text { Dimensions } \\
\text { of structural } \\
\text { units, mm }\end{array}$} & \multicolumn{6}{|c|}{ Content of structural units, $\%$} & \multirow{3}{*}{$\begin{array}{c}\text { Variation } \\
\text { coefficient, } \\
\%\end{array}$} \\
\hline & \multirow[b]{2}{*}{ Average } & \multirow[b]{2}{*}{ Median } & Min. & Max. & $\mathrm{L}_{0.25}$ & $\mathrm{~L}_{0.75}$ & \\
\hline & & & \multicolumn{2}{|c|}{$\begin{array}{l}\text { Amplitude interval: } \\
\qquad \mathrm{A}=\text { max-min }\end{array}$} & \multicolumn{2}{|c|}{$\begin{array}{l}\text { Normalized interval: } \\
\Delta \mathrm{H}=\mathrm{L}_{0.75}-\mathrm{L}_{0.25}\end{array}$} & \\
\hline \multicolumn{8}{|c|}{ Reference to $F 1(R>+0.70)$} \\
\hline $3-5$ & 18.9 & 20.1 & 5.12 & 33.9 & 15.2 & 24.3 & 38.9 \\
\hline $1-3$ & 26.1 & 28.0 & 9.20 & 38.3 & 22.1 & 30.9 & 30.5 \\
\hline \multicolumn{8}{|c|}{ At $R>-0.70$} \\
\hline $1-0.5$ & 16.0 & 12.9 & 7.09 & 38.7 & 10.5 & 19.8 & 48.3 \\
\hline $1-0.25$ & 26.9 & 24.6 & 11.3 & 50.0 & 20.1 & 33.5 & 37.1 \\
\hline $0.16-0.2$ & 5.19 & 4.64 & 0.31 & 17.7 & 1.55 & 7.40 & 73.1 \\
\hline 0.125 & 1.11 & 0.74 & 0.02 & 5.53 & 0.19 & 1.62 & 110.7 \\
\hline 0.10 & 0.42 & 0.24 & 0.01 & 2.28 & 0.11 & 0.53 & 117.6 \\
\hline$<0.25$ & 8.77 & 7.57 & 0.41 & 21.9 & 2.27 & 10.5 & 75.6 \\
\hline \multicolumn{8}{|c|}{ Reference to $F 2(R>-0.70)$} \\
\hline $7-0.25$ & 82.0 & 82.3 & 68.4 & 94.0 & 78.5 & 84.9 & 5.92 \\
\hline $5-0.10$ & 83.8 & 83.5 & 67.8 & 98.8 & 78.8 & 87.9 & 8.43 \\
\hline$>7+<0.25$ & 18.0 & 17.7 & 5.90 & 31.6 & 15.04 & 21.5 & 26.9 \\
\hline \multicolumn{8}{|c|}{ Reference to $F 3(R>-0.70)$} \\
\hline $0.071+<0.05$ & 2.05 & 1.95 & 0.13 & 14.15 & 0.55 & 2.56 & 121.3 \\
\hline
\end{tabular}



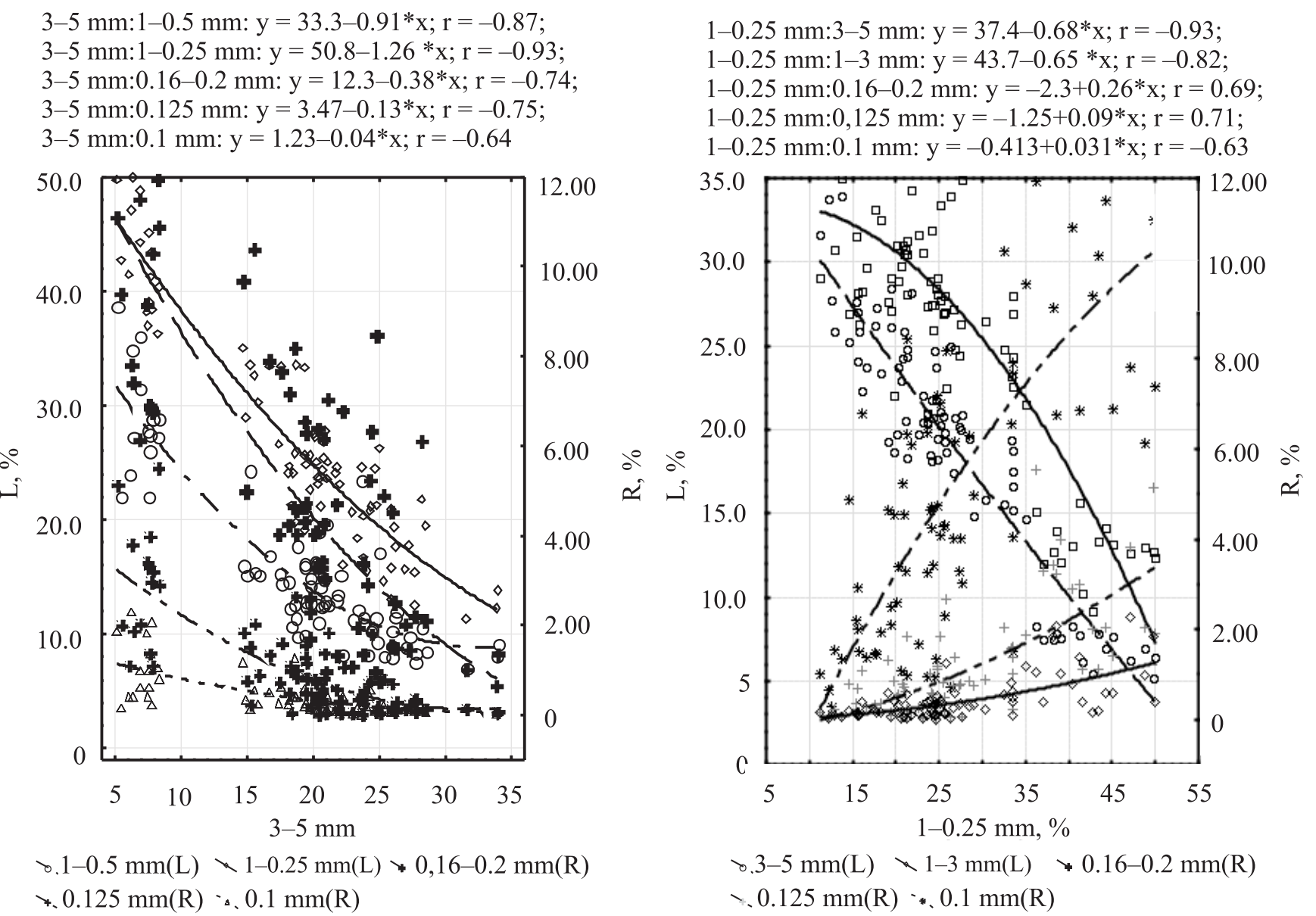

Fig. 2. The dependence between the content of macroaggregates and groups of microaggregates of the $<0.25 \mathrm{~mm}$ fraction in soil variants, the general model: by axis $\mathrm{L}-$ the reference of units of $3-5 \mathrm{~mm}$ and $1-3 \mathrm{~mm}$; by axis $\mathrm{R}$ - the reference of units of $0.16-0.2 \mathrm{~mm}, 0.125 \mathrm{~mm}, 0.1 \mathrm{~mm}$

size of soil particles from $0.16 \mathrm{~mm}$ to $0.125 \mathrm{~mm}$ the regression coefficients were regularly decreased from 0.34-0.36 down to 0.11 which demonstrated the decrease in the intensity of involving the particles of $<0.25 \mathrm{~mm}$ to the macroaggregates of the most valuable size. The interrelation between macroaggregates of $1-0.25 \mathrm{~mm}$, structured into smaller fractions of $1-0.5 \mathrm{~mm}$ and $0.5-0.25 \mathrm{~mm}$, and the soil particles of $0.16-0.2 \mathrm{~mm}$ was enhanced with the decrease in the size of macroaggregates. $0.27 \%$ of the increase in the number of soil particles of $0.16-0.20 \mathrm{~mm}$ could be attributed to one point of the increase in the content of units of 1-0.5 mm (Fig. 3).

In general, the content of soil units of $1-0.25 \mathrm{~mm}$ correlated with the most valuable units on the level of reverse strong correlation, and there was a $0.65-$ $0.68 \%$ decrease in the content of units of $1-0.25 \mathrm{~mm}$ per one point of their increase in the most valuable fraction. There was direct correlation between the content of soil particles of $0.16-0.20 \mathrm{~mm}$, and the increase in the content of units of $1-0.25 \mathrm{~mm}$ per one point was accompanied with the increase in the content of soil particles of $0.125 \mathrm{~mm}$ and $0.1 \mathrm{~mm}$.

The appraisal of the structural state of soil objects depending on the agrogenic impact requires introducing the notion of the coefficient of macroaggregate stability $\left(\mathrm{K}_{\text {macr }}\right)$, as a ratio between the sum of units of 5-1 mm and the units and soil particles of $1-0.1 \mathrm{~mm}$, calculated according to formula 1 :

$$
\mathrm{K}_{\text {macr }}=\frac{\Sigma(5-1) \mathrm{mm}}{\Sigma(1-0.1) \mathrm{mm}}
$$

The estimation of the microaggregate stability of soil requires introducing the notion of the coefficient of microaggregate stability $\left(\mathrm{K}_{\text {micr }}\right)$, as a ratio between the sum of units of $1-0.25 \mathrm{~mm}$ and the units and soil particles of $0.25-0.1 \mathrm{~mm}$, calculated by the formula 2 :

$$
\mathrm{K}_{\text {micr }}=\frac{\Sigma(5-0.25) \mathrm{mm}}{\Sigma(0.2-0.1) \mathrm{mm}}
$$




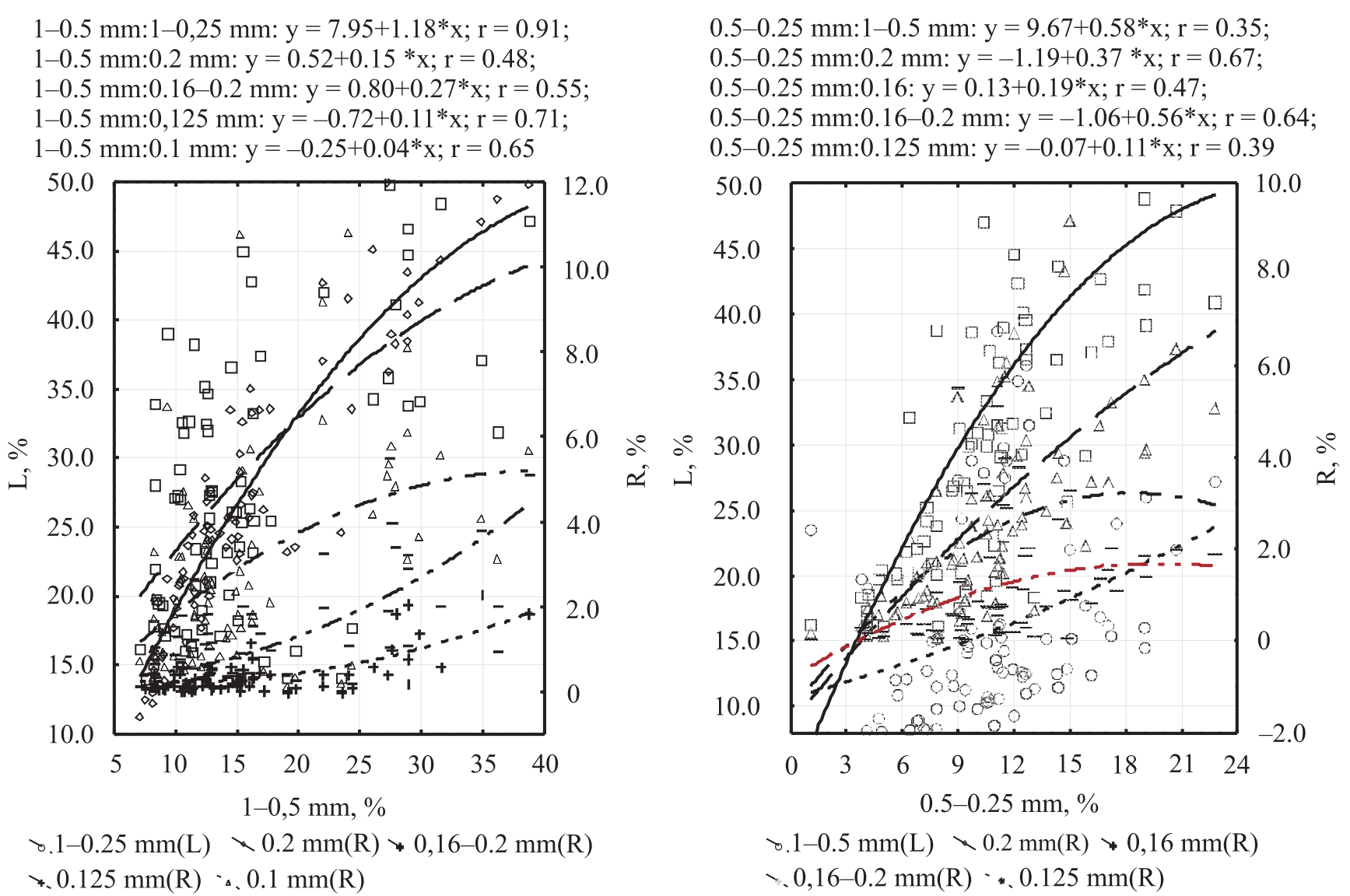

Fig. 3. The dependence of the content of small fractions of agronomically valuable interval with structured groups of microaggregates of $<0.25 \mathrm{~mm}$, the general model: by axis $\mathrm{L}$ - the reference of units of $1-0.5 \mathrm{~mm}$; by axis $\mathrm{R}$ - the reference of the content of units of $0.16 \mathrm{~mm}, 0.16-0.2 \mathrm{~mm}, 0.125 \mathrm{~mm}, 0.1 \mathrm{~mm}$

Below we calculated the intervals of estimating the state of soil structure by the coefficients of micro- and macroaggregation (Table 4).

It was found that $\mathrm{K}_{\text {macr }}$ had a reference by factor $\mathrm{F}_{1}$ correlation on the level of strong direct correlation, $\mathrm{K}_{\text {micr }}$ had a reference on the level of reverse correlation $\mathrm{r}>-0.70$ by $\mathrm{F}_{2}$, which helps us consider the mentioned ratios as reliable indicative ones for the estimation of macro- and microaggregate states of soils under different agrogenic impacts.

The results of calculating the correlation coefficients demonstrated that $\mathrm{K}_{\text {macr }}$ had a close connection to the group of soil particles of $1-0.1 \mathrm{~mm}: \mathrm{r}=0.75 \pm 0.02$; $\mathrm{r}^{2}=0.56$, and the connection of $\mathrm{K}_{\text {micr }}$ to particles of $0.2-1 \mathrm{~mm}$ had medium reverse correlation: $\mathrm{r}=-0.65 \pm$ $\pm 0.02 ; r^{2}=0.43$. Therefore, the regression equations are as follows:

$\mathrm{K}_{\text {macr }}=9.72-1.47 * \mathrm{x} ; \mathrm{r}=-0.65 ; \mathrm{r}^{2}=0.43$, where $\mathrm{x}-$ $\sum^{\text {macr }}(0.2-0.1 \mathrm{~mm})$

$\mathrm{K}_{\text {macr }}=36.4-3.92 * \mathrm{x} ; \mathrm{r}=-0.75 ; \mathrm{r}^{2}=0.55$, where $\mathrm{x}-$ $\sum(1-0.1 \mathrm{~mm})$
Coefficient of microaggregate stability $\left(\mathrm{K}_{\text {micr }}\right)$ :

$\mathrm{K}_{\text {mic }} 8.85-0.24 * \mathrm{x} ; \mathrm{r}=-0.65 ; \mathrm{r}^{2}=0.43$, where $\mathrm{x}-$ $\sum(0.2-0.1 \mathrm{~mm})$

The normalization of $\mathrm{K}_{\text {macr }}$ and $\mathrm{K}_{\text {micr }}$ by the complex of 86 samples of air-dried sieving demonstrated that the average value of $\mathrm{K}_{\text {macr }}$ was 1.92 , normalized interval $\mathrm{K}_{\text {macr }}=0.71-2.4$ and $\mathrm{K}_{\text {macr }}=1.65-20.6$ by the normalized interval with $10 \%$ reliability. The variation coefficient $\mathrm{K}_{\text {macr }}$ was $92.5 \%$, which demonstrated a high level of variability to the change in the structural state of soil objects. According to the calculations, the average value of $\mathrm{K}_{\text {micr }}=8.61$. According to the normalized interval $\mathrm{K}_{\text {micr }}=2.51-7.31$, and by the normalized one $\mathrm{K}_{\text {micr }}=1.65-20.6$, and with the variation coefficient of $149 \%$, which demonstrated high variability of $\mathrm{K}_{\text {micr }}$ while estimating the changes in the structural state of soils under agrogenic impact.

To confirm the abovestated, Table 5 presents the estimation of $\mathrm{K}_{\text {macr }}$ and $\mathrm{K}_{\text {micr }}$ on variants with different fertilization, soil tillage and maintaining a fallow on 
Table 4. The estimation of the state of soil structure by the coefficients of micro- and macroaggregation

\begin{tabular}{l|c|c|c}
\hline \multirow{2}{*}{ Quantiles } & \multicolumn{2}{|c|}{ Value intervals: } & \multirow{2}{*}{ Level of structuredness } \\
\cline { 2 - 3 } & $\mathrm{K}_{\text {micr }}$ & $\mathrm{K}_{\text {macr }}$ & Very low \\
\hline $\mathrm{L}_{0.1}$ & $<1.65$ & $<0.54$ & Low \\
$\mathrm{L}_{0.1}-\mathrm{L}_{0.25}$ & $1.65-2.50$ & $0.55-0.70$ & Medium \\
$\mathrm{L}_{0.25}-\mathrm{L}_{0.50}$ & $2.51-3.95$ & $0.71-1.75$ & Above medium \\
$\mathrm{L}_{0.50}-\mathrm{L}_{0.75}$ & $3.96-7.80$ & $1.76-2.40$ & High \\
$\mathrm{L}_{0.75}-\mathrm{L}_{0.90}$ & $7.80-15.5$ & $2.41-2.90$ & Very high \\
$>\mathrm{L}_{0.90}$ & $>15.5$ & $>2.91$ & \\
\hline
\end{tabular}

Table 5. The impact of the fertilization system, soil tillage and maintaining the fallow on the coefficients of macro- and microaggregation of soil variants in the Forest-Steppe

\begin{tabular}{c|c|c|c|c|c|c|c}
\hline \multirow{2}{*}{$\begin{array}{c}\text { Type of technogenic impact and } \\
\text { maintaining }\end{array}$} & \multicolumn{5}{|c}{ Dimensions of structural units, $\mathrm{mm}$} \\
\cline { 2 - 7 } & $0.2-0.1$ & $1-0.25$ & $\begin{array}{c}\mathrm{K}_{\text {micr }}=\underline{1-0.25 \mathrm{~mm}} \\
0.2-0.1 \mathrm{~mm}\end{array}$ & $5-1$ & $1-0.1$ & $\begin{array}{c}\mathrm{K}_{\text {macr }}=\underline{5-1 \mathrm{~mm}} \\
1-0.1 \mathrm{~mm}\end{array}$ & $5-0.25$ \\
\hline
\end{tabular}

Meadow-chernozem low-humus carbonate medium-clay heavy-loamy soil on forest-like clay

\begin{tabular}{l|c|c|c|c|c|c|c}
\hline \multicolumn{7}{c}{ Sugar beet } \\
\hline No fertilizers & 2.16 & 23.1 & 10.7 & 55.3 & 25.3 & 2.19 & 78.4 \\
1 dose of NPK & 2.61 & 20.2 & 9.30 & 55.2 & 20.8 & 2.64 & 79.5 \\
1.5 dose of NPK & 3.02 & 23.6 & 7.80 & 51.0 & 26.7 & 1.91 & 74.6 \\
\hline \multicolumn{7}{|c}{ Clover } \\
\hline No fertilizers & 4.33 & 19.6 & 4.53 & 53.6 & 23.9 & 2.24 & 73.2 \\
1.5 dose of NPK & 4.50 & 17.8 & 3.96 & 55.2 & 22.3 & 2.47 & 73.0 \\
fallow & 4.46 & 19.9 & 4.47 & 58.9 & 22.1 & 2.67 & 78.3 \\
\hline \multicolumn{7}{l}{ Typical low-humus heavy-loamy light-clay chernozem on forest-like clay } \\
\hline No till - 1 dose of NPK & 15.8 & 19.6 & 1.24 & 20.8 & 35.3 & 0.59 & 70.9 \\
No till - 2 doses of NPK & 10.8 & 24.9 & 2.31 & 20.8 & 35.7 & 0.58 & 77.4 \\
Plowing - 1 dose of NPK & 8.68 & 23.9 & 2.75 & 14.9 & 52.7 & 0.28 & 83.9 \\
Plowing-2 doses of NPK & 15.1 & 27.6 & 1.83 & 19.6 & 42.7 & 0.46 & 75.2 \\
\hline
\end{tabular}

Gray forest low-humus heavy-loamy light-clay soil on carbonate forest-like clay

\begin{tabular}{l|c|c|c|c|c|c|c}
\hline No fertilizers & 8.90 & 24.1 & 2.71 & 47.9 & 28.9 & 1.66 & 72.1 \\
NPK & 9.7 & 29.1 & 3.01 & 42.8 & 39.8 & 1.08 & 71.9 \\
1 dose of NPK + 1.0 $\mathrm{Ha} \mathrm{CaCO}_{3}$ & 8.41 & 8.98 & 3.28 & 44.9 & 17.4 & 2.58 & 72.4 \\
2 doses of NPK + 1.0 $\mathrm{Ha} \mathrm{CaCO}_{3}$ & 8.41 & 27.6 & 3.28 & 44.9 & 35.9 & 1.25 & 72.4 \\
Fallow & 7.74 & 21.3 & 2.74 & 51.5 & 28.9 & 1.78 & 72.7 \\
\hline
\end{tabular}

soil variants of the Forest-Steppe. On the meadowchernozem soil, while maintaining the fallow $\mathrm{K}_{\text {macr }}=$ $=2.67$. When fertilizers were introduced in the increasing dose, $\mathrm{K}_{\text {macr }}$ decreased 1.4 times in the variant with the double dose of fertilizers, while $\mathrm{K}_{\text {micr }}$ increased 1.75-2.39 times. When perennial grasses were grown, $\mathrm{K}_{\text {micr }}$ decreased 1.09-1.19 times as compared to the fallow, and the value of $K_{\text {micr }}$ decreased 1.13 times after the introduction of a single dose. Under these agrotechnical effects, the meadow-chernozem soil had high soil resistance to the degradation traits in the structural state of soil.

When gray forest soil was introduced mineral fertilizers in a single dose with liming, it promoted 1.45fold increase in $\mathrm{K}_{\text {macr }}$, and under the other effects the resistance of soil remained on the level of the fallow and decreased 1.65 times. After introducing a single and a double dose of mineral fertilizers into gray forest 
soil as compared to the fallow, the coefficient of microaggregate stability $\left(\mathrm{K}_{\text {micr }}\right)$ tended to increase at the absolute value, and in case of liming - increased 1.2 times which demonstrated high resistance to agrotechnical impact and strong possibility of the soil variant reclamation.

Typical low-humus heavy-loamy light-clay chernozem on forest-like clay had the lowest stability by the index of $\mathrm{K}_{\text {macr }}=0.28-0.59$. By the technology of zero tillage the indices of $K_{\text {macr }}$ were higher as compared to $\mathrm{K}_{\text {macr }}$ under systematic plowing. On the contrary, the dispersion stability was higher under systematic plowing, where the introduction of the double dose of fertilizers resulted in the 1.5 -fold decrease in $\mathrm{K}_{\text {micr }}$, which demonstrated the negative impact of both systematic zero tillage and high doses of mineral fertilizers. In its turn, typical low-humus non-deep heavy-loamy lightclay chernozem on forest-like clay was the least resistant soil variant to agrotechnical impacts as compared to two other investigated soils.

\section{DISCUSSION OF STUDY FINDINGS}

Agronomic soil science widely uses the principle of studying soil as a natural body with its hierarchy, according to which the ion-molecular level is the initial one, followed by the level of elementary soil particles and the level of structural soil aggregates. This principle, called by A.D. Voronin and E.V. Shein the principle of hierarchy in soil study, is of great relevance: the knowledge of properties of elementary soil particles allows passing from the ESP level to quantitative description of structural micro- and macroaggregates. The determination of the levels of structural organization of soil should consider specific interactions between different levels, not just any of them, which are conditioned by the specificities of the soil-forming process, which serves as a criterion of isolating each subsequent structural level in the systematic organization of soil. These interpretations of the levels of structural organization of soil were used by N.A. Kachynsky, S.V. Nerpin and A.F. Chudnovsky (Nerpin S, and Chudnovsky A., 1967) to isolate the microaggregate level to analyze porosity and formation of pores of different sizes. The fractal approach to describing gel structures, forming interparticle bonds, which manifest the behavioral specificities of the "solid phase - soil solution - soil air" during the creation of structural soil units was also suggested (Malinovsky E and Shein E, 2003; Fedotov G et al, 2005). The level of aggregate organization of structural memory of soil or soil architecture is also relevant (Wilding $\mathrm{L}$ and Lin H, 2006).
The novelty of the studies lies in the fact that the use of improved methods of instrumental and state-of-theart statistical analysis of the data on air-dried sieving (soil fractioning in air-dried state) of soil variants in the Forest-Steppe under agrogenic and post-agrogenic loading helps determine deeper direction of structurization on different levels of its organization and defining the resistance of soil variants to the manifestation of agrophysical degradation under anthropogenic impact (introduction of mineral fertilizers and ways of tillage).

Our studies determined the main regularities in the transformation of the structural state of chernozems in the Forest-Steppe zone under long-term agrogenic and post-agrogenic transformation. A general regularity was determined: regardless of the state of chernozem, the share of 3-0.5 mm units in the sum of agronomically valuable $(7-0.25 \mathrm{~mm})$ units, irrespective of their number, was $51-54 \%$, and the increase in the agrogenic burden accelerates the formation of heavyloamy fraction ( $>7 \mathrm{~mm}$ ) up to $30 \%$, of agronomically non-valuable units - up to $35.6 \%$ (Demydenko O, 2019; 2020).

Simultaneous study of the change in the structural state of soil on several levels of its organization ensures obtaining objective and integral information and determining the level, on which a negative process of agrophysical degradation starts on the level of structural-aggregate composition. The re-grouping of the structural-aggregate state of soil in terms of dimensions occurs in soil-genetic valuable interval of macro- and microaggregates and soil particles (5$0.1 \mathrm{~mm}$ ) depending on the type of soil. The structured microaggregates, smaller than $0.25 \mathrm{~mm}$ in the total amount, performing a self-regulating function in the processes of forming the soil macrostructure, are mainly involved in the fraction of $1-0.25 \mathrm{~mm}$ units and, albeit less so, in the $5-1 \mathrm{~mm}$ units. During the destruction of the macrostructure, the number of soil particles of $<0.25 \mathrm{~mm}$ increases, re-grouping into less valuable microaggregates of $<0.16 \mathrm{~mm}$ with further saturation of low-active fractions of $<0.1 \mathrm{~mm}$ which is an indicator of decreasing or increasing the resistance to degradation processes.

\section{CONCLUSIONS}

The structurization of microaggregate fractions under $0.25 \mathrm{~mm}$ into separate constituents allowed enhancing the reliability of approximation of exponential equations of the distribution of structural units for the 
agronomically valuable interval to the level of $r^{2}>0.7$ and determining the persistence and anti-persistence of the very distribution series. The structured microaggregates smaller than $0.25 \mathrm{~mm}$ in the total amount perform a self-regulating function in the processes of forming the soil macrostructure, getting mainly involved in the fraction of $1-0.25 \mathrm{~mm}$ units and, albeit less so, in the 5-1 mm units. During the destruction of the macrostructure, the number of soil particles of $<0.25 \mathrm{~mm}$ increases, re-grouping into less valuable microaggregates of $<0.16 \mathrm{~mm}$ with further saturation of low-active fractions of $<0.1 \mathrm{~mm}$ which is an indicator or a criterion of increasing the resistance to degradation processes.

The application of factor and cluster analyses allowed substantiating, on the macroaggregate and microaggregate levels with the existing agronomically valuable interval of structural units $(7-0.25 \mathrm{~mm})$, the reasonability of isolating soil-genetic interval of valuable structural units in the interval of $5-0.1 \mathrm{~mm}$, where the units of $5-1 \mathrm{~mm}$ bear the load of the direct functional action and the ones in the interval of $1-0.1 \mathrm{~mm}$ - reverse functional or self-regulating action.

The following coefficients were suggested for the estimation of structural state of soil variants: macroaggregate and microaggregate stability as a ratio between the sum of 5-1 $\mathrm{mm}$ aggregates and the sum of $1-0.1 \mathrm{~mm}$ aggregates, and the ratio between the sum of $1-0.25 \mathrm{~mm}$ and the sum of $0.2-0.1 \mathrm{~mm}$ aggregates, respectively, which allow estimating the state of soil structure under the impact of fertilization, the way of tillage and maintaining in the post-agrogenic state.

The simultaneous study of the change in the state of soil structure on the main soils in the Forest-Steppe on macroaggregate and microaggregate levels allowed determining that, depending on soil type, in the range of soil-genetic intervals of valuable structural units of soil there is a re-grouping of microaggregates and ESP of the constituents of the fractions of $<0.25$ $\mathrm{mm}$, mainly involved in structural aggregates of $1-$ $0.25 \mathrm{~mm}$ and, less so, in most valuable structural units of 5-1 mm.

The meadow-chernozem soil was found to be the most resistant to anthropogenic impacts (introduction to mineral fertilizers): $\mathrm{K}_{\text {macr }}=1.91-2.19$, and in case of sowing perennial grasses with the introduction of fertilizers $\mathrm{K}_{\text {macr }}=2.24-2.47$. Gray forest soil $\left(\mathrm{K}_{\text {macr }}=\right.$ $=1.08-2.58$ ) was found to be less resistant to the introduction of mineral fertilizers, and typical chernozem was the most susceptible: $\mathrm{K}_{\text {macr }}=0.28-0.59$. The microaggregation coefficient $\left(\mathrm{K}_{\text {micr }}\right)$ increased in the row - typical chernozem $>$ gray forest soil $>$ meadowchernozem soil.

Adherence to ethical principles. All experiments described in this paper were non animal based.

Conflict of interest. Authors declare no conflict of interest.

Financing. This study was not financed by any specific grant from financing institutions in the state, commercial or non-commercial sectors.

\section{Оцінка агрогенного структуротворення грунтових відмін різного способу використання в Лісостепу}

\section{С. Ю. Булигін ${ }^{1}$, О. В. Демиденко ${ }^{2, *}$,}

В. А. Величко ${ }^{3}$, М. А. Ткаченко ${ }^{4}$, С. В. Вітвіцький ${ }^{1}$

${ }^{1}$ Націона́льний університе́т біоресу́рсів і природокористува́ння України, вул. Героїв Оборони, 15, Київ, 03041

2 Черкаська державна сільськогосподарська дослідна станція ННЦ «Інститут землеробства НААН» вул. Докучаєва, 13, с. Холоднянське, Смілянський р-н, Черкаська обл., Україна, 20731

${ }^{3}$ ННЦ «Інститут грунтознавства та агрохімії ім. О. Н. Соколовського», вул. Чайковська, 4, Харків, Україна, 61024

${ }^{4}$ ННЦ «Інститут землеробства НААН»

Київська обл., Києво-Святошинський район, селище міського типу Чабани,

вул. Машинобудівників, буд. 2-Б, Україна, 08162

E-mail: agrogumys@ukr.net 2,*, agrovisnyk@ukr.net ${ }^{3}$

Мета. Розробити загальну нормовану статистичну модель організації структурного стану досліджуваних грунтів, виявити вектор спрямованості та критерії оцінки структуроутворення грунтових відмін Лісостепу на макро-, мікроагрегатному рівнях організації для отримання об'єктивної і цілісної інформації про якісний стан структури грунту та встановлення критичного рівня деградації, за якого втрачається остаточна стійкість проти її прояву. Методи. Польовий (досліджені агрофізичні властивості найпоширеніших відмін Лісостепу України: сірого лісового грунту, лучно-чорноземного грунту, чорнозему типового), лабораторний (повітряносухе просіювання грунту), статистично-аналітичні (фрактальний, факторний, кластерний, непараметричної статистики). Результати. Спряжене вивчення зміни стану грунтової структури на основних грунтах Лісостепу на двох ієрархічних рівнях дало змогу встановити наявність грунтово-генетичного інтервалу цінних структурних окремостей. Здійснено оцінку рядів розподілу структурних окремостей грунту за розміром на предмет стійкості за фрактальними показниками, а також структуризація агрономічно нецінної фракції мікроагрегатів розміром $<0,25$ мм, що дало змогу підсилити 
достовірність апроксимації трендів експоненти рівнянь розподілу окремостей до рівня $\mathrm{R}^{2}>0,7$ та визначити персистентність і антиперсистентність самих рядів розподілу, тобто, стійкість або трендовість. Залежно від типу грунту відбувається перегрупування складових структури грунту за розміром, а мікроагрегати у сумі $<0,25$ мм долучаються, більшою мірою, до структурних агрегатів 1-0,25 мм та, меншою мірою, до більш цінних структурних окремостей розміром $>1$ мм. Висновки. Встановлено, що найбільш стійким до антропогенного впливу (внесення мінеральних добрив і способи обробітку) виявився лучно-чорноземний грунт в якому коефіцієнт макроагрегованості досягав високого рівня, а за висіву багаторічних трав 3 внесенням добрив дуже високого рівня. Менш стійким до внесення мінеральних добрив був сірий лісовий грунт, а найбільш вразливим до агрофізичної деградації був чорнозем типовий: коефіцієнт макроагрегованості був на дуже низькому рівні. Коефіцієнт мікроагрегованості зростав від чорнозему типового до сірого лісового та до лучночорноземного грунтів, що свідчить про зростання гумусованості і біогенності у представленому ряду грунтових відмін.

Ключові слова: структурний стан грунту, мікроагрегати, макроагрегати, елементарні грунтові частки, факторний аналіз, кластерний аналіз, факторний аналіз, коефіцієнт мікроагрегованості, коефіцієнт макроагрегованості, генетично-грунтовий інтервал цінних агрегатів.

\section{REFERENCES}

An SS, Huang YM, Zheng FL, Yang JG (2008) Aggregate characteristics during natural revegetation on the loess plateau. Pedosphere. 18(6):809-816. doi: 10.1016/S10020160(08)60077-6.

Bazykina GS (2014) Soils within the steppe and dry steppe zones under anomalous weather conditions in the last tens years. Dokuchaev Soil Bulletin. (73):54-81. doi: 10. 19047/0136-1694-2014-73-95-120.

Bryk M (2004) Indeces of shape in the classification of soil structure. Polish J Soil Sci. 37(1):1-10

Bulygin SYu, Lisetskyi FN Pat. 2026550 Russia, MKI 19956 G $01 \mathrm{~N} 33 / 24$. Method of determining the impact of treatment on soil; Bulygin S.Yu. Lisetskyi F.N. No. 4920150; Appl. 19.03.91; Publ. 9.01.95, 8 p. (in Russian).

Bulygin SYu, Achasov AB, Achasova AO, Papchenko OV, Panasenko VM (2014) System of estimating and pre-dicting soil quality (status, concept and algorithms). K.: Ahrarna nauka. 240 p. ISBN 978-966-540-380-7 (in Ukrainian).

Cheverdin YuI (2008) Dlitel'nost' raspashki i fizicheskoe sostoyanie chernozemov Kamennoj Stepi. Zemledelie. (3): 28-30.

Demydenko OV (2019) Structural state of chernozem after long-term post-agrogenic transformation. Bull. Agric. Sci. (12):13-22. doi: 10.31073/agrovisnyk201912-02. (in Ukrainian).
Demydenko OV (2020) Structural state of chernozems of Forest-Steppe zone at agrogenic impact. Bull Agric Sci. (4):5-14. doi: 10.31073/agrovisnyk202004-01.

Elliott ET (1986) Aggregate structure and carbon, nitrogen, and phosphorus in native and cultivated soils. Soil Sci Soc Am J. 50(3):627-633. doi: 10.2136/sssaj1986.0361 $5995005000030017 \mathrm{x}$.

Fedotov GN, Tretiakov YuD, Dobrovolsky GV, Pozdniakov AI, Shein EV, Nekliudov AD, Zhukov DV, Pakhomov EI (2005) Phenomenon of formation of periodic colloid structures in soils. Diploma to the opening of MAANOIRAEN-MAANO No. 286. Scientific discoveries (collection of scientific discoveries, scientific ideas, scientific hypotheses, 2005). M., 2006, p. 34-37. (in Russian).

Garcia-Oliva F, Oliva M, Sveshtarova B (2004) Effect of soil macroaggregates crushing on $\mathrm{C}$ mineralization in a tropical deciduous forest ecosystem. Plant Soil. 259(12):297-305. doi: 10.1023/B:PLSO.0000020978.38282.dc.

Gorban VA (2016) The role of the structure to provide biogeocenotic soil functions. Ecol noospherol. 27(34):89-96. doi: 10.15421/031617.

Horn R, Fleige H (2000) Prediction of the mechanical strength and ecological properties of subsoils for a su-stainable landuse. Proc. of the workshop Experiences with the impact of subsoil compaction. Uppsala. Sweden., p. 109-121.

Jimenez JJ, Lorenz K, Lal R (2011) Organic carbon and nitrogen in soil particle-size aggregates under dry tropical forests from Guanacaste, Costa Rica - Implications for within-site soil organic carbon stabilization. Catena. 86(3):178-191. doi: 10.1016/j.catena.2011.03.011.

Kershens $M$ (1992) Significance of humus content for soil fertility and nitrogen cycle. Pochvovedenie. (10):122-131.

Kholodov VA (2013) The capacity of soil particles for spontaneous formation of macroaggregates after a wetting-drying cycle. Euras Soil Sci. 46(6):660-667. doi: 10.7868/S0032180X13040072.

Kholodov VA, Yaroslavtseva NV, Frid AS, Lazarev VI (2016) Interpretation of data on the aggregate composition of typical chernozems under different land use by cluster and principal component analyses. Euras Soil Sci. 49(9):1026-1032. doi: 10.7868/S00 32180X160-90070.

Kuznetsova I, Azovtseva N, Bondarev A (2011) Norms of change of physical properties of soils of steppe, arid and semi-desert zones of European Russian territories. Dokuchaev Soil Bulletin. (67):3-19. doi: 10.19047/ 0136-1694-2011-67-3-19.

Kuznetsova IV, Utkaeva VF, Bondarev AG (2014) Norms of changing physical properties of arable chernozems in the Steppe zone of European Russian territory in conditions of intense agricultural use. Pochvovedenie. (1):71-81. doi: 10.7868/S0032180X14010067. (in Russian).

Malinovsky EYu, Shein EV (2003) Role and significance of organic matter in the formation and stability of soil aggregates. Pochvovedenie. (1):53-61. (in Russian). 
Medvedev VV (1990) Variability of optimal soil density and the reasons for it. Pochvovedenie. (5):20-31 (in Russian).

Medvedev VV, Slowinska-Jurkievicz A, Bryk M (2012) Physical degradation of soils, its diagnostics, areas of distribution and ways of prevention. Gruntoznavstvo. 13 (1-2):5-22.

Medvedev VV (2013) Time and spatial heterogenization of soil ploughed up. Gruntoznavstvo. 14(1-2):5-21.

Medvedev VV, Plisko IV, Bigun ON (2014) Comparative characterization of the optimum and actual parameters of Ukrainian chernozems. Euras Soil Sci. 47(10):10441057. doi: 10.1134/S106422931410007X.

Medvedev VV (2016) Agrizem as a new 4-dimensional polygenetic formation. Gruntoznavstvo. 17(1-2):5-20. doi: 10.15421/041601.

Moiseev KG, Boitsova LV,Goncharov VD (2014) Analyses of soil humus dinamics by fractal methods. Agrophysics. (13):1-8.

Nerpin SV, Chudnovsky AF (1967) Physics of soils. M.: Nauka, $584 \mathrm{p}$.

Nichols KA, Toro $M$ (20110 A whole soil stability index (WSSI) for evaluating soil aggregation. Soil Till Res. 111(2):99-104. doi: 10.1016/j.still.2010.08.014.

Pirmoradian N, Sepaskhah AR, Hajabbasi MA (2005)
Application of fractal theory to quantify soil aggregate stability as influenced by tillage treatments. Biosyst Eng. 90(2):227-234. doi: 10.1016/j.biosystemseng. 2004.11.002.

Polupan MI (2019) Ukrainian Agronomic Soil Science: Textbook. In 2 parts; Part 1: Historical stages of development. Soil formation factors. Regularities of soil formation on an ecological-genetic parametric systemic basis, their agronomic properties, and fertility. Kyiv: Agrarna nauka, 426 p. ISBN 978-966-540-475-0.

Six J, Bossuyt H, Degryze S, Denef K (2004) A history of research on the link between (micro) aggregates, soil biota, and soil organic matter dynamics. Soil Till Res. 79(1):7-31. doi: 10.1016/j.still.2004.03.008.

Slowinska-Jurkewicz A, Kolodziej B, Bryk M (2004) Wplyw zabiegow agrotecnicznych na structure gleby pylowey ocena morfometryczna macroporow. Annales UMCS, Sec. E. 59(1):329-335.

Wilding LP, Lin HS (2006) Advancing the frontiers of soil sciences towards a geoscience. Geoderma. 131(12):257-274. doi: 10.1016/j.geoderma.2005.03.028.

Zaryshnyak AS, Baliuk SA, Lisovoy MV (2016) Stationary field test-trials of Ukraine. Kharkiv: Smuhasta Typohrafiya, p. 265. ISBN 617-7387-31-1(IC15467). 